\title{
BLACK-FOOTED FERRETS AND RECREATIONAL SHOOTING INFLUENCE THE ATTRIBUTES OF BLACK-TAILED PRAIRIE DOG BURROWS
}

\author{
Dean E. Biggins ${ }^{1,2}$, Shantini Ramakrishnan ${ }^{1}$, Amanda R. Goldberg ${ }^{1}$, and David A. Eads ${ }^{1}$
}

\begin{abstract}
Black-tailed prairie dogs (Cynomys ludovicianus) plug burrows occupied by black-footed ferrets (Mustela nigripes), and they also plug burrows to entomb dead prairie dogs. We further evaluated these phenomena by sampling connectivity and plugging of burrow openings on prairie dog colonies occupied by ferrets, colonies where recreational shooting was allowed, and colonies with neither shooting nor ferrets. We counted burrow openings on line surveys and within plots, classified surface plugging, and used an air blower to examine subsurface connectivity. Colonies with ferrets had lower densities of openings, fewer connected openings (suggesting increased subsurface plugging), and more surface plugs compared to colonies with no known ferrets. Colonies with recreational shooting had the lowest densities of burrow openings, and line-survey data suggested colonies with shooting had intermediate rates of surface plugging. The extent of surface and subsurface plugging could have consequences for the prairie dog community by changing air circulation and escape routes of burrow systems and by altering energetic relationships. Burrow plugging might reduce prairie dogs' risk of predation by ferrets while increasing risk of predation by American badgers (Taxidea taxus); however, the complexity of the trade-off is increased if plugging increases the risk of predation on ferrets by badgers. Prairie dogs expend more energy plugging and digging when ferrets or shooting are present, and ferrets increase their energy expenditures when they dig to remove those plugs. Microclimatic differences in plugged burrow systems may play a role in flea ecology and persistence of the flea-borne bacterium that causes plague (Yersinia pestis).
\end{abstract}

REsumen.-El perro llanero de cola negra (Cynomys ludovicianus) tapa las madrigueras que ocupan los hurones de patas negras (Mustela nigripes). También tapa las madrigueras para enterrar los cuerpos de otros perros llaneros muertos. Llevamos a cabo más evaluaciones de este fenómeno al hacer un muestreo de la conectividad y el taponamiento de madrigueras en colonias de perros llaneros ocupadas por hurones, en colonias donde se permite la cacería recreativa y también en colonias en donde no se permite la cacería ni tampoco habitan hurones. Contamos las madrigueras abiertas en líneas de muestreo y dentro de los cuadrantes, clasificamos el taponamiento de la superficie y usamos un ventilador para examinar la conectividad subterránea de las madrigueras. Las colonias con hurones tuvieron una densidad menor de madrigueras abiertas, menos madrigueras conectadas entre sí (lo cual indica un aumento en el taponamiento del subsuelo) y más taponamientos hechos en la superficie en comparación con las colonias en las que no se han encontrado hurones. De las 3 categorías de colonias, las colonias en donde se permite la cacería recreativa tuvieron la menor densidad de madrigueras abiertas; a su vez, los datos de las líneas de muestreo indicaron que estas colonias tuvieron un promedio intermedio de taponamientos en la superficie. El grado de taponamientos subterráneos y en la superficie podría tener consecuencias en la comunidad del perro llanero al cambiar la circulación del aire y las rutas de escape de los sistemas de las madrigueras, así como al alterar las relaciones energéticas. Los taponamientos hechos por los perros llaneros podrían disminuir el riesgo que tienen de ser depredados por los hurones, pero podría aumentar el riesgo de ser presa del tejón (Taxidea taxus); sin embargo, la complejidad de esta disyuntiva aumenta si los taponamientos aumentan el riesgo de que los hurones se vuelvan presa de los tejones. Los taponamientos y las excavaciones aumentan la energía que los perros llaneros utilizan cuando hay hurones o cacería; por otro lado, los taponamientos hechos por los perros llaneros aumentan el consumo de energía de los hurones al tener que cavar para destapar los hoyos. Las diferencias microclimáticas en los sistemas de taponamientos de las madrigueras podrían influenciar la ecología de las pulgas y la persistencia de la bacteria transmitida por las pulgas que ocasiona la peste (Yersinia pestis).

Attributes of rodent burrows include measures of tunnels (e.g., diameter, angle of incline, depth), density of surface openings, configurations of surface openings (e.g., presence or absence of soil mounds), connectivity of openings via tunnels, and blockage of connecting tunnels with soil plugs. Burrow plugging is observed in many rodent species that occupy burrow systems. For instance, in Columbian ground squirrels (Otospermophilus columbianus) and Merriam's kangaroo rats (Dipodomys merriami), plugging behavior is commonly observed during the breeding season, where it may shield preweaned litters in natal dens from

${ }^{1}$ United States Geological Survey, Fort Collins Science Center, 2150 Centre Avenue, Building C, Fort Collins, CO 80525.

2E-mail: dean_biggins@usgs.gov 
infanticide (Reynolds 1960, McLean 1978). Werner et al. (2005) also noted plugging behavior in pocket gophers (Thomomys bottae navus) in response to the presence of cold temperatures and light, while Thomas (1974) reported that eastern chipmunks (Tamias striatus) plug food caches underground and appear to use earthen plugs as protection against predators. Burrow plugging seems to be a natural manifestation of "defensive burying" and other substrate movement responses that have been measured in psychometric experiments on captive rodents over many years (De Boer and Koolhaas 2003).

We investigated several attributes of the burrows of black-tailed prairie dogs, including density and configuration of surface openings (discussed below), but connectivity of openings as influenced by plugging was a primary focus. Black-tailed prairie dogs (Cynomys ludovicianus, henceforth "prairie dogs") surfaceplug openings to their burrow systems (Smith 1958, Henderson et al. 1969, Sheets et al. 1971) and sometimes construct subsurface plugs within tunnels (Sheets et al. 1971). Various explanations have been proposed for burrow plugging by prairie dogs. Female prairie dogs plug "auxiliary" openings to nesting chambers containing recently born pups, presumably in defense against infanticide (Hoogland 1995: 29). Shooting and poisoning induce plugging behavior by prairie dogs (Campbell and Clark 1981), suggesting prairie dogs plug burrow openings to entomb dead conspecifics belowground (Smith 1958). The presence of blackfooted ferrets (Mustela nigripes, henceforth "ferrets"), which are semifossorial obligate predators of prairie dogs (Sheets et al. 1972, Campbell et al. 1987), and snakes also elicit plugging by prairie dogs (Hillman 1968, Henderson et al. 1969, Fortenbery 1972, Halpin 1983, Eads and Biggins 2012). Subsurface plugs that result from changes in tunnel design by the prairie dogs (Wilcomb 1954) might reduce prairie dogs' risk of predation by semifossorial predators, such as ferrets.

Prairie dogs must expend energy to dig and plug burrows. Burrowing can be 360-3400 times more energetically expensive than walking an equal distance (Vleck 1979, but see Bozinovic et al. 2005), and costs can vary by a factor of 9 depending on whether the soil is sand or clay (Vleck 1981). Costs of soil manipulation can be split into those associated with shearing packed soil and those associated with transport of loose soil. Shearing costs are likely low when prairie dogs use loose soil and litter around openings to create surface plugs, but these costs could be high when subsurface plugs are created using soil excavated from within a tunnel. Transport costs can vary due to steepness and length of the incline (Luna and Antinuchi 2007). Complete replacement of plugged burrows with new burrow construction, as observed by Halpin (1983), would involve high energy expenditures.

The indirect impacts of ferret presence likely extend beyond the energetic expenditures of digging and plugging. Prairie dogs may be trading time spent plugging for time that they might use for foraging, resting, or other activities. Also, the presumed benefits of multi-opening burrows, such as air circulation (Vogel et al. 1973, King 1984) and predator avoidance (Hoogland 1995), are likely compromised by surface and subsurface plugging. For example, American badgers (Taxidea taxus) commonly dig into burrows to capture prey (Michener 2004) and may be able to detect single-opening systems, where prey presumably would be most vulnerable (Eads and Biggins 2008 and other citations therein). Surface plugs would also seem to reduce the number of burrow openings that are available to prairie dogs seeking refuge from raptors, coyotes (Canis latrans), or other predators that attack aboveground. If prairie dog plugging behavior increases risk of predation for prairie dogs, it might also do so for ferrets, and this behavior might be an example of a prey species (prairie dog) trading increased vulnerability to generalist predators for reduced vulnerability to a presumably more efficient specialist predator (Hassell and May 1986, Hanksi et al. 1991).

We add anecdotally that our own excavations by shovel and steel bar to recover radio transmitters and the remains of ferrets killed by badgers (Biggins 2000, Biggins et al. 2006b), along with our experience with sampling prairie soils using hydraulic soil machines (Eads personal observations), have left a lasting impression regarding the difficulties and energy required to penetrate $\geq 2 \mathrm{~m}$ vertically through prairie sod and compacted subsoils. These experiences have generated great respect for the animals that routinely create burrow systems in this environment. Because of the difficulties 
in excavating prairie dog burrows (King 1955, Sheets et al. 1971), subsurface attributes of prairie dog burrow systems have rarely been studied. A few studies have documented complex burrow systems with multiple connections (Wilcomb 1954, Sheets et al. 1971, Verdolin 2008), as well as simple tunnels with a single opening at the surface (Stromberg 1978). In this study we aimed to further examine influences of ferrets and recreational shooting on rates and locations of burrow plugging by prairie dogs. To investigate influences of ferrets, we examined surface plugging and subsurface burrow connectivity in prairie dog colonies occupied by ferrets and in colonies with no known ferret presence. We also examined plugging and connectivity in prairie dog colonies where shooting was allowed and in colonies protected from shooting.

We anticipated that prairie dog colonies with resident ferrets would exhibit higher rates of surface and subsurface plugging than colonies with no known ferrets (because prairie dogs might use both forms of plugging in defense against ferrets). On colonies where shooting was permitted, we anticipated higher rates of surface plugging compared to colonies protected from shooting (because prairie dogs might bury the remains of their shot counterparts). In addition, presence of shooting or ferrets might reduce rates of burrow connectivity because these factors tend to reduce numbers of prairie dogs (i.e., excavators that maintain burrow systems), perhaps leaving burrow systems in disrepair.

Presence of ferrets or shooting might also affect density and configuration of prairie dog burrow openings. Configurations of openings have been classified according to presence or absence of soil mounds (Hoogland 1995). During construction of a new burrow system, prairie dogs leave dome-shaped deposits of soil around the opening at which the excavation began (Smith 1958, Hoogland 1996). Systems with multiple openings are thought to be created when prairie dogs dig upward at a steep angle and break though the surface at new locations (King 1955, Sheets 1970). The additional openings created do not have mounds until the prairie dogs construct them by scraping surface soil into crater-shaped mounds surrounding the new openings. Some openings with dome-shaped mounds remain as singleopening burrows. We thus hypothesized that openings with dome-shaped mounds would have less frequent subsurface connections than would other types of openings. That relationship might be modified, however, if prairie dogs dig new burrow systems soon after they surface-plug existing burrows as reported by Halpin (1983). Newly added burrows would be expected to alter ratios of mound types present and rates of connectivity associated with various types of openings. With increased prairie dog mortality (due to shooting or predation by ferrets) or increased frequency of burrows occupied by ferrets, we thus predicted an increase in the ratio of burrow openings with domeshaped mounds compared to other types of mounds due to increased construction of new burrows. On colonies occupied by ferrets or on colonies where shooting was allowed, we might expect that openings with crater-shaped mounds or no mounds would have lower rates of connectivity to other openings than on colonies without ferrets or shooting.

\section{Methods}

We sampled 15 prairie dog colonies on Badlands National Park and adjacent portions of the Buffalo Gap National Grasslands, South Dakota (Fig. 1). On many sites, vegetation is dominated by western wheatgrass (Pascopyrum smithii), blue grama (Bouteloua gracilis), and buffalograss (Bouteloua dactyloides). Where cattle graze with prairie dogs, various species of forbs dominate the landscape. We examined effects of ferrets and shooting on surface plugging rates and subsurface connectivity of burrow openings by contrasting colonies with ferrets but no shooting, colonies with shooting but no ferrets, and colonies with neither shooting nor ferrets (i.e., "control" colonies, Table 1). Shooting was prohibited on colonies believed to be occupied by ferrets, so effects of shooting and ferret occupancy could be separately evaluated. However, interactions between effects of ferrets and shooting could not be adequately assessed.

We defined colony boundaries using outermost burrow openings and the density criteria of Biggins et al. (1993). We classified the colonies to be sampled as occupied by ferrets if female ferrets with litters were detected on them via spotlight surveys (Biggins et al. 2006a) during summer 2009, but we did not attempt to estimate ferret densities. Unoccupied colonies 


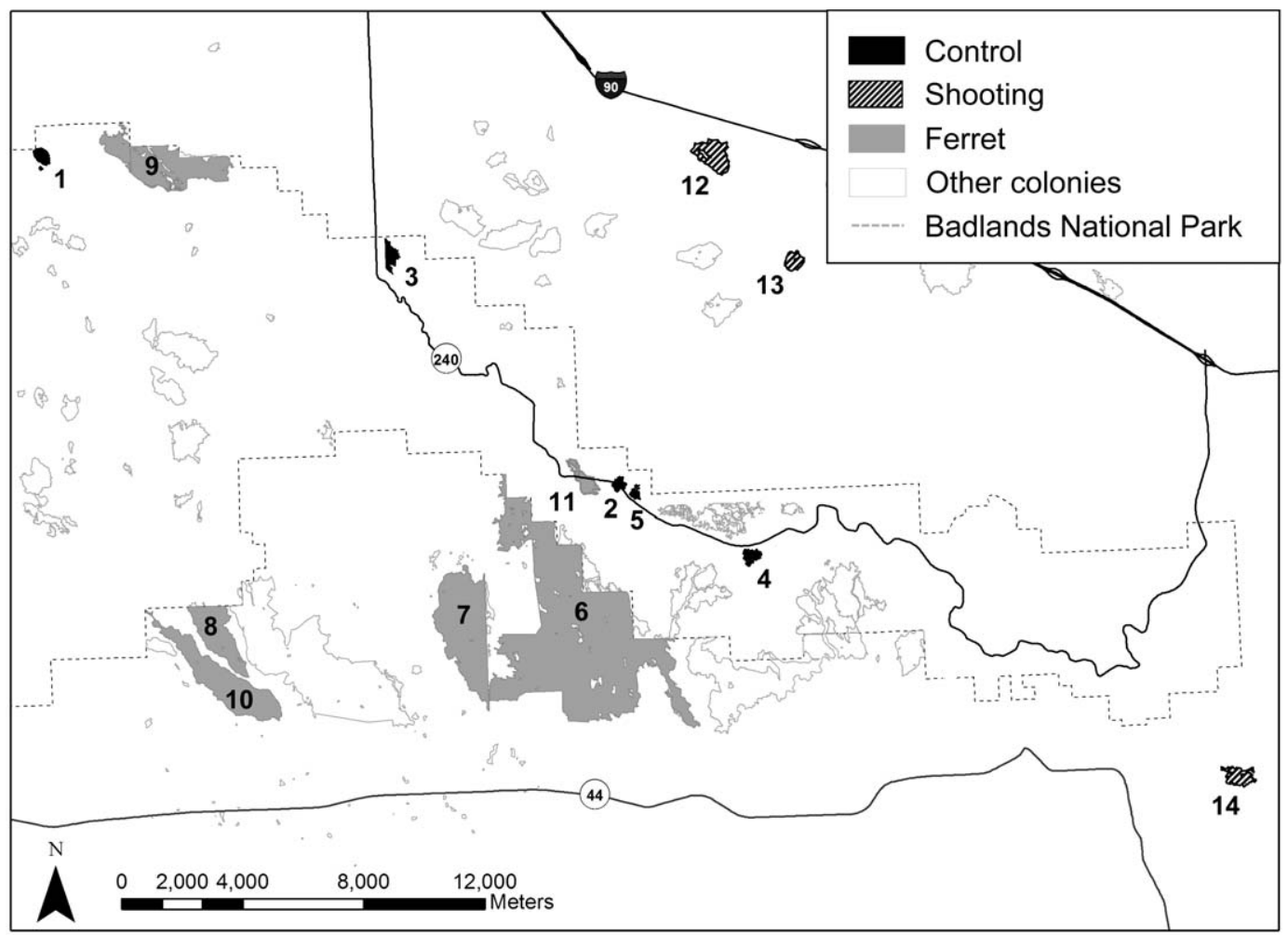

Fig. 1. Black-tailed prairie dog colonies in Badlands National Park and adjacent areas of Buffalo Gap National Grassland, South Dakota, on which connectivity and surface plugging of burrow openings were sampled during 2009. Colony numbers correspond to those in Table 1.

TABLE 1. Number of burrow openings sampled at black-tailed prairie dog colonies in Badlands National Park and adjacent areas of Buffalo Gap National Grassland, South Dakota. Treatment groups are colonies known to be occupied by blackfooted ferrets (ferret), colonies where prairie dog shooting was allowed (shooting), and colonies with neither ferrets nor shooting (control). Numbers correspond to the locations on Figure 1.

\begin{tabular}{lclccc}
\hline & & & \multicolumn{2}{c}{0.073 -ha plots } & Line surveys \\
\cline { 5 - 5 } Colony & Number & Treatment & Focal burrows & Openings & Openings \\
\hline Antelope & 1 & Control & 12 & 223 & 33 \\
East Quinn & 2 & Control & 12 & 255 & 26 \\
Pinnacles & 3 & Control & 18 & 268 & 57 \\
Prairie Winds & 4 & Control & 12 & 239 & 35 \\
West Basinger & 5 & Control & 17 & 299 & 41 \\
Agate North & 6 & Ferret & 12 & 95 & 34 \\
Conata West & 7 & Ferret & 12 & 87 & 66 \\
North Exclosure & 8 & Ferret & 12 & 151 & 91 \\
Roberts A & 9 & Ferret & 12 & 176 & 33 \\
Roberts B & 9 & Ferret & 12 & 142 & 16 \\
South Exclosure & 10 & Ferret & 12 & 285 & 88 \\
West Quinn & 11 & Ferret & 12 & 201 & 49 \\
Bigfoot EP 6 & 12 & Shooting & 12 & 99 & 10 \\
Bigfoot EP 10 & 13 & Shooting & 12 & 106 & 14 \\
White River & 14 & Shooting & 13 & 269 & 58 \\
TotaL & & & 192 & 2895 & 651 \\
\hline
\end{tabular}


were those that lacked detection of ferrets by spotlight surveys or snow tracking (Biggins et al. 2006a) during the previous 12 months. We did not attempt to quantify the amount of shooting on colonies where shooting was allowed.

\section{Surface and Subsurface Plugging}

Burrow sampling involved examination of burrow openings for surface plugging and subsurface connectivity. We tallied surface plugs and total numbers of burrows on plots and line surveys. To determine burrow connectivity, we tested burrow systems with forced air from a gasoline-powered blower, a noninvasive means of determining connectivity (Eads and Biggins 2008, Biggins 2012).

From July through October 2009, we sampled 192 randomly selected focal burrow openings (i.e., unplugged openings) in the 15 study colonies (Table 1). We counted the total number of burrow openings and the number of surface-plugged openings within $15.24 \mathrm{~m}$ of the focal opening, creating a burrow-centered circular plot of 0.073 ha. Surface-plugged burrow openings were those for which the opening was completely filled with soil and litter (Henderson et al. 1969). As weathering degrades the fresh soil deposited into a burrow opening by prairie dogs, plugged openings presumably lose their definition, becoming nonvegetated mounds and depressions (without evidence of openings) that later support vegetation. Because these transitions are continuous, defining categories is difficult. We classified as plugged all nonvegetated mounds and small depressions lacking openings, without regard to evidence of recent soil disturbance.

At a burrow-centered circular plot, we used the blower on the focal burrow opening to test for an open connection to other burrow openings within the plot. We inserted the delivery tube of the blower into the focal burrow opening, sealed the space between the tube and tunnel walls with plastic bags and soil, and started the blower to create positive air pressure within the burrow system. Feathers were sequentially placed into all other burrow openings that were not surface-plugged; airflow within a tunnel caused feathers to be expelled from the opening. We sequentially plugged (with plastic bags and soil) burrow openings within the plot that were found to be connected to the focal opening. This action increased airflow to any remaining openings that were connected. After each opening was plugged, all remaining openings were reexamined with feathers. Because we had no noninvasive method to measure burrow structure in 3 dimensions, we measured the 2-dimensional Euclidian distance between the openings for focal burrows and burrows that exhibited airflow. Those distances underestimate actual distances through the connecting tunnels because tunnels must descend and ascend and often take circuitous routes laterally. During sampling, burrow openings were categorized with regard to the type of mound surrounding the opening (dome, crater, or nonmounded; sensu Sheets 1970).

We used Mann-Whitney tests to compare total burrow densities on colonies with ferrets or shooting to densities on colonies with neither source of mortality. We used logistic regression to compare plots on ferret-occupied colonies to plots on control colonies with regard to connectivity of burrow openings and with regard to surface plugging. The logistic regression procedure was repeated to compare plots on colonies where shooting was allowed to plots on control colonies. Binomial response variables were presence or absence of openings connected to the focal burrow and presence or absence of surface-plugged burrow openings. Because densities of burrow openings would be expected to influence the probability that a focal burrow would be connected to other burrow openings, we retained the total number of burrow openings that were not surface-plugged within a 0.073 -ha plot as a covariate in the statistical models of connectivity and surface plugging rates. Predictor variables of primary interest were black-footed ferret occupancy of a colony and whether or not prairie dog shooting was allowed. We initially evaluated multivariate models using an information theoretic approach, with models ranked via Akaike's information criterion (AIC). We used likelihood ratio (LR) tests to further compare certain nested submodels to more general models. For data from the 0.073ha plots, we created point estimates and confidence intervals using simple models that did not include the relationship involving total burrow openings.

Numbers and Types of Burrow Openings

Because openings having crater-shaped mounds or no mounds are thought to be 
terminus openings for systems initiated from an opening with a dome-shaped mound, their connectivity is expected to be more responsive to factors that alter the frequency of subsurface plugging (such as shooting and ferret-induced mortality). We thus separately compared these categories of colonies with respect to connectivity rates for openings with dome-shaped mounds and openings with combined crater-shaped mounds or no mounds. Separation of the sample into categories of burrow mounds produced inadequate sample sizes in some groups, so we compared pooled data from colonies with shooting and colonies with ferrets to data from the control colonies with neither of these sources of mortality. We used 2 simple logistic regression models: one for openings with dome-shaped mounds and one for openings with craters or no mounds.

Our 0.073-ha plots did not allow unbiased estimates of rates of surface plugging or ratios of types of burrow openings because the plots were centered on a burrow opening that was not surface-plugged. Thus, we also walked along lines of 1-m width and variable length that completely crossed the colonies, starting at a random point at the edge of the colony, following a predetermined azimuth, and ending at the opposite edge of the colony. Along the lines, we classified burrow openings as crater, dome, or nonmounded and noted surface plugs. In total, we classified 651 burrow openings on the 15 colonies where the 0.073 ha plots were sampled (Table 1).

We used contingency table analyses to compare the 3 categories of colonies with respect to ratios of types of burrow openings. And we used logistic regression as described above to assess rates of surface plugging at burrow openings with dome-shaped mounds and non mounded openings. We censored crater-shaped mounds from this logistic regression analysis because the rarity of plugging there caused convergence problems during iterative maximum likelihood estimation. For all analyses, we assessed the effect of ferret occupancy using colonies with no shooting and the effect of shooting using colonies with no ferrets.

\section{Results}

Density of burrow openings was $239.0 \mathrm{ha}^{-1}$ on colonies with neither ferrets nor shooting, compared to $159.9 \mathrm{ha}^{-1}$ on colonies with shooting (Mann-Whitney $\chi^{2}{ }_{1}=23.904, P<$ 0.001 ) and $167.2 \mathrm{ha}^{-1}$ on colonies with ferrets (Mann-Whitney $\chi^{2}{ }_{1}=31.138, P<0.001$ ). These estimates are likely higher than true densities of burrow openings because the 0.073-ha plots were always centered on an opening. Focal burrow openings were connected to a maximum of 9 additional openings in the plots, and there were up to 8 surfaceplugged burrow openings in these plots. Because a few connected burrow openings were near the perimeters of the plots, it is likely that a few additional subsurface connections existed beyond the 15.24-m radius of sampling.

In the analysis of ferret effects on connectivity of burrow openings within 0.073-ha plots, competitive models ( $\Delta$ AIC within 3 units of model with lowest AIC) retained the ferret variable (Table 2). The ferret variable was also highly influential when the general model with effects of ferrets and total burrows was compared to the reduced model with total burrows only (LR $\left.\chi^{2}{ }_{1}=7.814, P=0.005\right)$. Presence of ferrets was associated with relatively few plots having connected burrow openings (Fig. 2). In a separate analysis, effect of shooting was not influential (Fig. 2) as judged by the most supported model with constants only (Table 2), and explanatory power of shooting was weak when assessed by model contrasts as above $\left(\mathrm{LR} \chi^{2}{ }_{1}=0.664, P\right.$ $=0.415)$.

In the analysis of ferret effects on surface plugging within plots, competitive models again retained the ferret variable (Table 2), and a contrast of models as above strongly supported the contention that ferret presence influenced the frequency of surface plugging $\left(\mathrm{LR} \chi^{2}{ }_{1}=16.928, P<0.001\right)$. Ferret presence was associated with an abundance of plots with burrow openings that were surface plugged (Fig. 2). Similar to results for subsurface connections, there was little evidence for effect of shooting on frequencies of surface plugging in plots. The most supported model had only the constant (Table 2), and explanatory power of shooting was weak when assessed by model contrasts as above $\left(\mathrm{LR} \chi^{2}{ }_{1}=0.275\right.$, $P=0.600)$.

We found support for our expectation that differences in rates of connectivity due to shooting and ferret occupancy would be more detectable for burrow openings with cratershaped mounds and those without mounds 


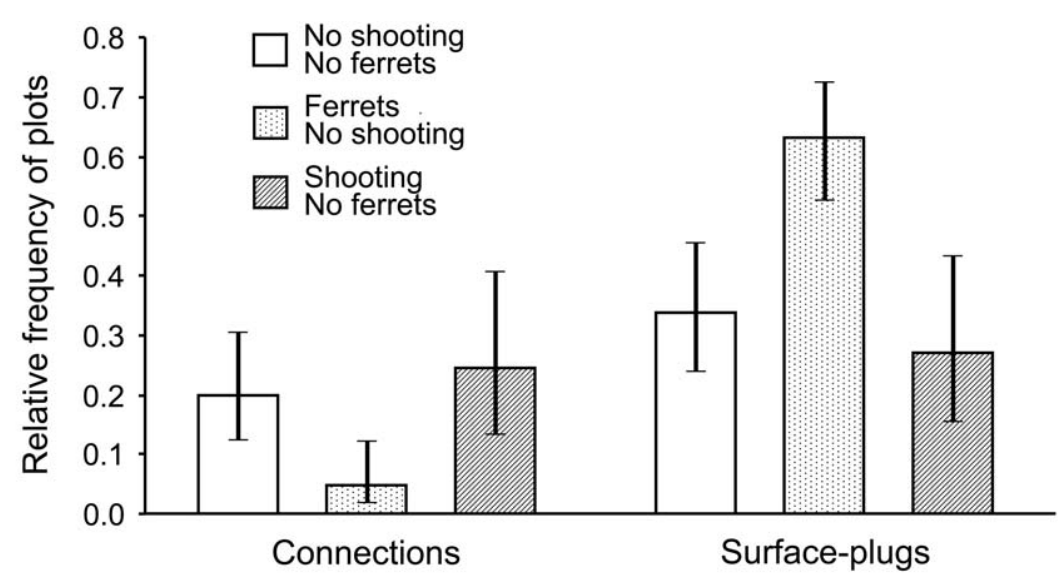

Fig. 2. Comparison of black-tailed prairie dog colonies occupied by black-footed ferrets, colonies not known to be occupied by ferrets, and colonies with and without recreational shooting in regard to surface-plugged burrow openings and subsurface connections of burrow openings. Estimates are proportions (and 95\% CIs) of 0.073-ha plots with $\geq 1$ surface-plugged burrow opening and with $\geq 2$ burrow openings connected with tunnels.

TABLE 2. Evaluation of frequencies of subsurface connections and surface plugging rates at burrow openings on colonies with and without black-footed ferrets (BFF) or shooting (SHOOT). Total numbers of nonplugged burrow openings (TB) was used as a control variable. Data were derived from 0.073-ha plots.

\begin{tabular}{|c|c|c|c|}
\hline Model & Log-likelihood & AIC & $\Delta \mathrm{AIC}$ \\
\hline \multicolumn{4}{|l|}{ Subsurface connection, ferret } \\
\hline Constant $+\mathrm{BFF}+\mathrm{TB}$ & -51.323 & 108.646 & 0.000 \\
\hline Constant + BFF $+\mathrm{TB}+(\mathrm{BFF} \times \mathrm{TB})$ & -50.532 & 109.064 & 0.418 \\
\hline Constant + TB & -55.230 & 114.459 & 5.814 \\
\hline \multicolumn{4}{|l|}{ Subsurface connection, shooting } \\
\hline Constant $+\mathrm{TB}$ & -55.751 & 115.503 & 0.000 \\
\hline Constant + SHOOT + TB & -55.419 & 116.839 & 1.336 \\
\hline Constant + SHOOT $+\mathrm{TB}+($ SHOOT $\times \mathrm{TB})$ & -55.419 & 118.839 & 3.336 \\
\hline \multicolumn{4}{|l|}{ Surface plug, ferret } \\
\hline Constant + $\mathrm{BFF}+\mathrm{TB}$ & -98.917 & 203.835 & 0.000 \\
\hline Constant + BFF $+\mathrm{TB}+(\mathrm{BFF} \times \mathrm{TB})$ & -98.899 & 205.799 & 1.964 \\
\hline Constant + TB & -107.381 & 218.763 & 14.928 \\
\hline \multicolumn{4}{|l|}{ Surface plug, shooting } \\
\hline Constant $+\mathrm{TB}$ & -67.058 & 138.115 & 0.000 \\
\hline Constant + SHOOT $+\mathrm{TB}+($ SHOOT $\times \mathrm{TB})$ & -65.840 & 139.680 & 1.565 \\
\hline Constant + SHOOT + TB & -66.920 & 139.840 & 1.725 \\
\hline
\end{tabular}

(both presumed to be terminus openings) than for openings with dome-shaped mounds. On colonies with assumed prairie dog mortality from shooting or ferrets, the rate of connectivity for burrow openings with crater-shaped mounds or no mounds was 0.051 (95\% CI, 0.0190.127), compared to 0.179 (95\% CI, 0.092-0.317) for such openings on control colonies $\left(\mathrm{LR} \chi^{2}{ }_{1}\right.$ $=5.069, P=0.024)$. In contrast, there was little difference $\left(\operatorname{LR} \chi^{2}{ }_{1}=0.025, P=0.874\right.$ ) between these categories of colonies regarding rates of connectivity for openings with dome-shaped mounds $(0.214,95 \%$ CI 0.115 $0.363 ; 0.231,95 \%$ CI $0.108-0.428)$.
Logistic regression analyses of line-survey data were consistent with plot data with respect to surface plugging of burrow openings (Fig. 3). In the assessment of ferret effects, the most supported model contained only the ferret variable (Table 3 ), and all competitive models also had the ferret variable. Ferret effect was highly influential, as suggested by comparison of the model with ferrets and mound types to the model with only mound types $\left(\mathrm{LR} \chi^{2}{ }_{1}=37.034, P<0.001\right)$. Thus, the lower-ranking competitive models relate to questions about additional effects of mound types (main effect and interaction with 


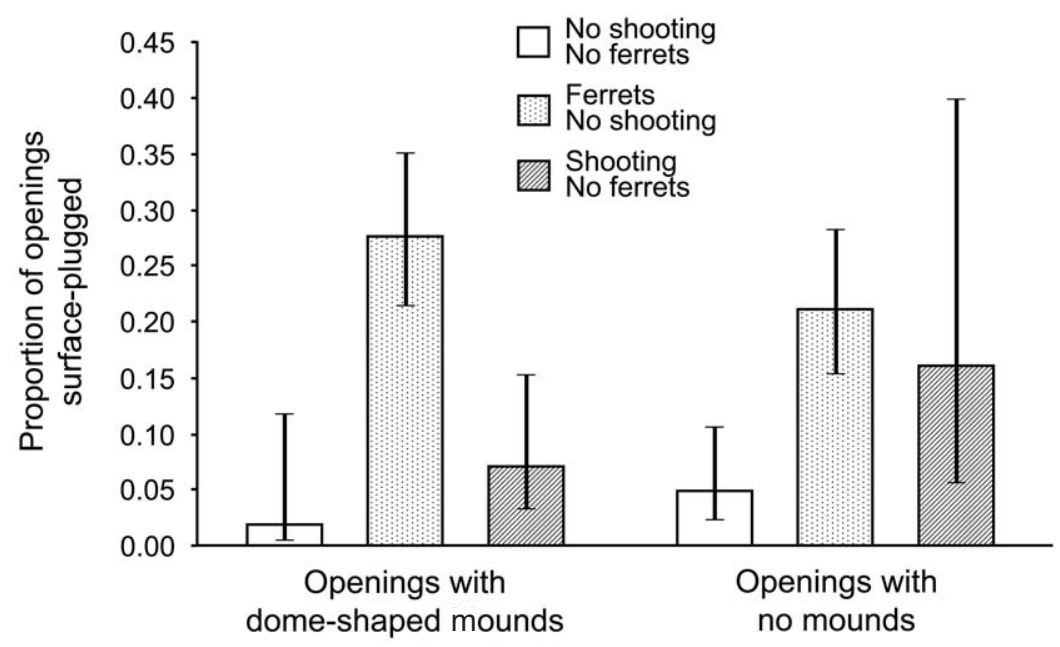

Fig. 3. Proportions (means and 95\% CIs) of surface-plugged burrow openings with dome-shaped mounds and surfaceplugged openings with no mounds on black-tailed prairie dog colonies occupied by black-footed ferrets, colonies not known to be occupied by ferrets, and colonies with and without recreational shooting.

TABLE 3. Evaluation of surface plugging rates at burrow openings with dome-shaped mounds and nonmounded openings (MOUND) on colonies with and without shooting (SHOOT) or black-footed ferrets (BFF). Data were from line surveys.

\begin{tabular}{lccc}
\hline Model & Log-likelihood & AIC & $\Delta$ AIC \\
\hline Black-footed ferret & & & \\
Constant + BFF & -200.519 & 405.038 & 0.000 \\
Constant + BFF + MOUND & -200.044 & 406.088 & 1.051 \\
Constant + BFF + MOUND + (BFF $\times$ MOUND) & -199.057 & 406.113 & 1.076 \\
Constant + MOUND & -218.561 & 441.122 & 36.084 \\
Constant only & -220.759 & 443.519 & 38.481 \\
Shooting & -52.592 & 111.183 & 0.000 \\
Constant + SHOOT + MOUND & -54.629 & 111.258 & 0.075 \\
Constant only & -53.558 & 111.258 & 0.075 \\
Constant + SHOOT & -54.548 & 113.095 & 1.912 \\
Constant + MOUND & -52.584 & 113.167 & 1.984 \\
Constant + SHOOT + MOUND + (SHOOT $\times$ MOUND) & & &
\end{tabular}

ferret). Because the model with the interaction was somewhat competitive $(\Delta \mathrm{AIC}=1.076)$, we generated estimates (Fig. 3) from that model. The interaction was likely produced by the disproportionately larger difference in plugging between colonies with and without ferrets for openings with dome-shaped mounds as compared to nonmounded openings (Fig. 3). Line-survey data showed somewhat equivocal effects of shooting on surface plugging. The most supported model retained mound effect and shooting effect, and a contrast of nested models as above supported an influence of shooting on the rate of surface plugging (LR $\left.\chi^{2}{ }_{1}=3.912, P=0.048\right)$. A model that was closely competitive $(\Delta \mathrm{AIC}=0.074)$, however, had only the constant (Table 3 ).
Ratios of various types of burrow openings varied among categories of colonies. On colonies without ferrets or shooting, nonmounded openings were most common (Fig. 4). Proportions of each mound type were much different from control colonies on colonies with ferrets but no shooting (Fig. $4 ; \chi^{2}{ }_{1}=23.863, P<$ 0.001 ) and on colonies with shooting but no ferrets (Fig. 4; $\chi^{2}{ }_{1}=77.583, P<0.001$ ). Dome-shaped mounds were prevalent on colonies with ferrets or shooting. Because crater mounds were relatively uncommon, differences in their ratios contributed less to overall variation than differences in ratios of other types of openings (e.g., craters produced $3.4 \%$ of the $\chi^{2}$ value in the evaluation of ferret effects and $15.9 \%$ in the evaluation of shooting effects). 


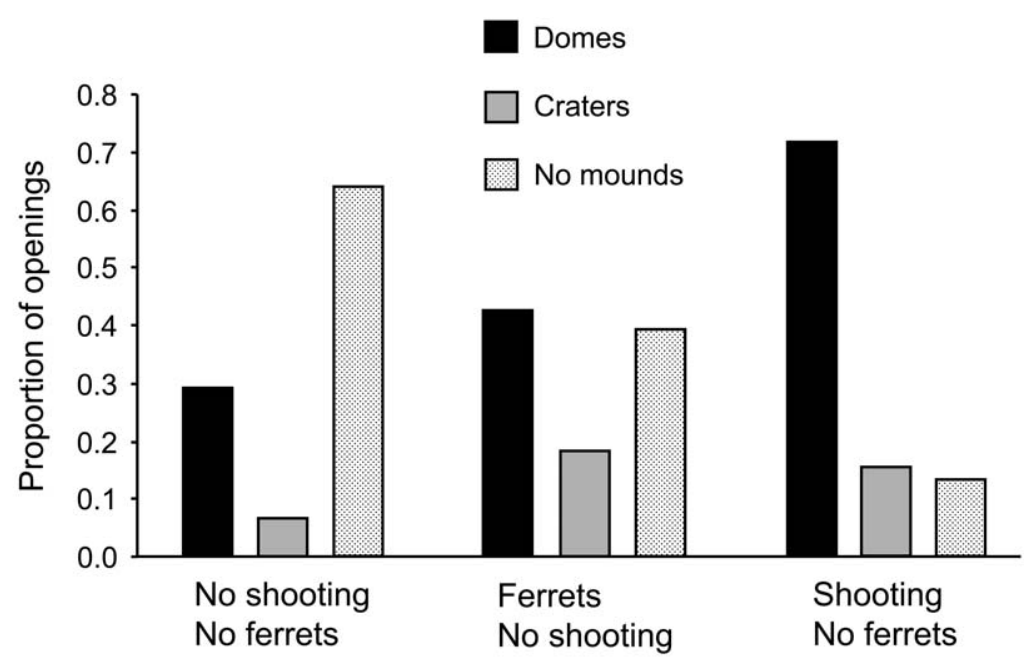

Fig. 4. Proportions of burrow openings with dome-shaped mounds, crater-shaped mounds, and no mounds on blacktailed prairie dog colonies occupied by black-footed ferrets, colonies with recreational shooting, and colonies with neither ferrets nor shooting.

Of the 48 openings found to be connected to the focal opening (the one with the blower), only $35.4 \%$ of connections were the dome-tocrater and dome-to-nonmounded openings that would be expected if prairie dogs construct burrow systems in the manner described. Dome-to-dome connections were unexpected but comprised $50.0 \%$ of the connections. The crater-to-crater and crater-to-nonmounded openings (14.6\%) might have been associated with complex multi-opening systems with several terminus openings (craters and nonmounded) that are therefore connected to each other and also to the origin at a dome.

\section{Discussion}

Our study design was constrained by a tendency for clustering in geographic distribution of the treatments. For example, ferrets inhabited relatively large colonies, and many of these colonies were in the southwest portion of the study area (Fig. 1). In addition, shooting was allowed only in areas away from Badlands National Park and where ferrets had not been released. Other factors might have influenced the results, including densities of prairie dogs, soil types, and vegetation composition. However, our replication within treatments should have helped to reduce effects of these variables because we expected variation in these factors within treatments. Also, in an attempt to account for prairie dog density, we used total burrow density as a control covariate in models that evaluated data from plots. Thus, although we could not control or measure some variables, the likely increase in statistical variation due to those factors did not seem to prevent detection of at least some relationships, and the potential for confounding interpretations did not seem high.

Within our study area, prairie dog colonies occupied by ferrets had burrow attributes that differed from colonies where ferrets were not recently detected. Overall, densities of burrow openings on ferret-occupied colonies were lower than those on control colonies. Although ferrets likely affect prairie dog population characteristics, the degree of impact has been debated (Henderson et al. 1969, Hillman and Linder 1973). Under the conditions of our study, our data suggest a $30 \%$ reduction in density of prairie dogs due to ferret occupancy if density of burrow openings is linearly correlated with density of prairie dogs (Biggins et al. 1993, 2006c).

Some effects of ferret presence are less direct than actual predation. Our data augment observations that occupancy of prairie dog colonies by black-footed ferrets causes increased surface plugging of burrow systems by prairie dogs (Smith 1958, Henderson et al. 1969, Sheets et al. 1971). Excavations of burrow systems (Sheets 1970) and rates of connectivity of 
burrow openings suggest prairie dogs create plugs belowground also. The effects of ferrets on plugging rates are not trivial. Surface plugging rates increased by a factor of 15.4 for dome openings and by a factor of 4.2 for crater and nonmounded openings, as suggested by our comparison of colonies with and without ferrets (Fig. 3). Considering remaining burrow openings that were not surface-plugged, subsurface connections had relative frequencies 4.1 times higher on colonies without ferrets than on colonies with ferrets (Fig. 2).

Prairie dogs tend to graze near burrow openings, perhaps to reduce risk of predation from animals that attack them aboveground (e.g., birds of prey). Spatially restricted foraging (Van Horne 2007) depletes vegetation surrounding burrow openings (Koford 1958). A reduction in the density of burrow openings due to surface plugging by prairie dogs would appear to influence the trade-off between quick access to safety and access to high quality and quantity of forage. With fewer available openings for escape, prairie dogs must choose whether to range farther from safety or consume less vegetation (or vegetation of lower quality). Thus, where surface-plugging rates are high due to presence of ferrets, prairie dogs might be presented with more difficult choices regarding nutrition and safety from other predators. Nutrition has been linked to reproductive performance (King et al. 1991, Hoogland 1995), to successful energy conservation via torpor (Lehmer et al. 2006), and to infanticide (Hoogland 1995, Ebensperger and Blumstein 2007). If nutrition is sacrificed to reduce risk of predation, additional indirect consequences of ferret presence on a colony might include reduced reproduction by prairie dogs and increased mortality of prairie dogs from infanticide and during torpor. The possible combinations of reduced nutritional input, increased energy expenditures, and increased rates of predation could substantially alter population growth rates of prairie dogs when ferrets are present. If so, the estimate of a $30 \%$ reduction in density of prairie dogs due to ferret occupancy might reflect not only the direct cost of predation by ferrets on prairie dogs, but also behaviorally mediated, indirect interactions (review in Creel and Christianson 2008) that elevate the costs of ferret presence.

Burrow plugging by prairie dogs might create other intriguing scenarios. By plugging burrows and reducing escape routes, prairie dogs might be trading decreased risk to ferrets for increased risk to more generalized predators, but they also might be increasing the risk of their specialized predator, the ferret, to badgers that prey on both prairie dogs and ferrets. Ferrets tend to use multi-opening burrow systems, perhaps as a defense against badgers (Biggins 2012). Although ferrets seem quite capable of quickly removing shallow surface plugs (Henderson et al. 1969), subsurface plugs can be long (Sheets 1970) and seem to reduce the availability of multiopening systems that ferrets prefer. Ferrets likely remove long plugs at times as suggested by removal of $>20 \mathrm{~kg}$ of soil during a single excavation event (Biggins et al. 2012) and removal of $45 \mathrm{~kg}$ of soil during a single night (Clark 1989). Nevertheless, ferrets do not seem to construct their own burrow systems, so we might assume that they are less efficient excavators than prairie dogs are. If so, plugs created by prairie dogs might be more quickly removed by prairie dogs than by ferrets, creating the possibility of differential risk for each species to excavation by badgers. If a prairie dog can reopen an alternative opening by plug removal at a rate faster than a pursuing badger can enlarge a burrow through the undisturbed soils surrounding the tunnel, an escape might be available for the prairie dog. The same might be true for a prairie dog being pursued by a digging ferret. The plausibility of this digging speed hypothesis as a defense is supported by observations on use of a similar tactic by kangaroo rats (Dipodomys spp.). These rodents appear to avoid threats within burrows by digging quickly through the soil remaining at the ends of tunnels that they have constructed with a terminus near the surface (White 2009).

We cannot be certain that the comparatively low rates of opening connectivity that we detected on prairie dog colonies occupied by ferrets are due to subsurface plugging by prairie dogs. That explanation is likely, however, because others have reported surface plugging in response to ferrets (Hillman 1968, Martin et al. 1984, Eads and Biggins 2012). We have observed captive and free-ranging prairie dogs in the act of plugging burrow openings when the associated burrow systems were known to be occupied by ferrets, and excavated burrow systems formerly occupied by ferrets often contained long subsurface plugs (Sheets 1970). Subsurface plugging by prairie dogs would seem to be a logical extension of 
surface plugging. It is unlikely that ferrets would do the plugging, because ferrets seem to prefer burrow systems with multiple openings (i.e., multiple routes of escape; Biggins 2012). Stromberg (1978) suggested that ferrets might prefer complex burrow systems, based on the excavations by Sheets et al. (1971) of ferret-occupied systems that had multiple openings in 15 of 18 cases. In that example, however, 10 of the 15 multi-opening systems were plugged with soil that likely would have prevented air circulation, and 2 of the remaining 3 were incompletely excavated (Sheets 1970). Thus, $28 \%$ of the burrow systems (i.e., 5 of 18) examined by Sheets (1970) might have had connected openings not detectable with our method or that of Stromberg (1978). Our testing strategy resulted in detection of $22 \%$ of burrow openings with at least one connection on colonies without ferrets (Fig. 1), much higher than the $8 \%$ rate that led Stromberg (1978:175) to conclude that "complex burrow systems were rare."

Perhaps our estimates of changes induced by presence of ferrets are underestimated. First, relatively recent occupancy by ferrets in the Roberts Colony might have allowed sufficient time for only small effects on the prairie dog population, and changes in burrow configurations likely have even greater lag times. Ferrets were released in 2004 on the Roberts Colony in Badlands National Park, and that colony likely did not attain ferret densities similar to other ferret-occupied colonies until 2007. Nevertheless, there were relatively stable ferret densities maintained for $>8$ years on other colonies we sampled. Second, we classified colonies (Table 1) with respect to their status in 2009, but ferrets had been present at least once previously on 2 of the small colonies where they were not known to be present in 2009. Burrow attributes on those colonies might to some degree reflect transitory occupancy by ferrets. Third, lack of detection does not assure that there were no ferrets present on colonies.

Effects of ferret presence on plugging by prairie dogs could have implications for species other than prairie dogs, ferrets, or badgers. For instance, air circulation becomes more restricted in plugged burrows. How might this affect burrow climate and how might those changes affect other associates of prairie dog burrows? Perhaps plugging causes average temperatures within burrows to be warmer in winter and cooler in summer, and it may cause humidity to be higher. Humidity and temperature are known to affect flea ecology (Krasnov 2008) and the flea-borne bacterium (Yersinia pestis) that causes plague (Gage and Kosoy 2005), a disease to which prairie dogs and ferrets are highly susceptible (Biggins et al. 2010, Matchett et al. 2010). Also, perhaps there are effects of these microclimatic influences on $Y$. pestis in soil, one possible maintenance environment for the bacteria (Baltazard 1964). The tendency for prairie dogs to plug burrows containing dead conspecifics also might lead to a positive feedback cycle that increases rates of plague transmission during an epizootic, wherein the process of plugging exposes prairie dogs to infected fleas that have left the underground carcasses of their counterparts and congregated near burrow openings.

Effects of shooting were less easily interpreted than effects of ferret presence. Overall burrow densities were lower on colonies where shooting was allowed than on colonies without shooting, and the ratios of the several types of mounds were clearly different. Although the line-survey data gave some support for more surface plugging on colonies with shooting than on those without shooting, the plot data did not provide additional evidence. Nevertheless, these data collectively are consistent with the hypotheses that (1) shooting reduces average densities of prairie dogs (Reeve and Vosburgh 2006), leading to reduced densities of burrow openings overall; (2) some prairie dogs that are shot die in burrows, rather than aboveground; (3) survivors tend to surfaceplug the burrows containing carcasses; and (4) increased numbers of plugged burrows lead to new burrow construction, creating a higher ratio of dome-shaped mounds. Effects of shooting on burrow plugging might be less dramatic than effects of ferrets simply because shooting instantly kills many prairie dogs aboveground and entombment by survivors is not possible, whereas ferrets tend to consume prairie dogs belowground and presumably leave portions of carcasses in burrows for varying periods.

Openings with crater-shaped mounds or no mounds are thought to be terminus openings usually associated, at least initially, with domeshaped mounds where the burrow construction originated. Lack of connectivity at these 
terminus openings should be a better indicator of subsurface plugging than lack of connectivity at dome-shaped mounds because the latter could also be indicative of single-opening burrows that are being constructed or that were discontinued before any connections were created. The different rates of connectivity for openings without dome-shaped mounds, compared to lack of variation in such rates for openings with domes, thus provide support for the hypothesis that at least some of the variation in connectivity of burrow openings on colonies with and without ferrets and shooting is due to subsurface plugging rather than construction of new systems that do not yet have multiple openings.

The preponderance of dome-to-dome connections we detected was unexpected given the hypothesized sequence of burrow construction (Sheets 1970). We presume that prairie dogs would find it impossible to excavate soil vertically through the nonmounded terminus burrows exemplified in the maps of Sheets (1970). There are several possible explanations for dome-to-dome connections. Perhaps prairie dogs dig some moderately sloped (rather than vertical) exit tunnels, which are later modified into domes by the delivery of subsoil from additional tunnel extensions to the surface at those formerly nonmounded openings. Perhaps erosion degrades domeshaped mounds that are later modified into crater-shaped mounds, or crater-shaped mounds might erode into domes if not continuously maintained as craters. We have also watched badgers destroy crater-shaped mounds. Perhaps prairie dogs eventually convert craters or nonmounded openings to domes because high domes serve as vantage points in close proximity to escape cover. Finally, prairie dogs might intersect existing tunnels as they dig new burrows, either by chance or by some method of detecting the existing tunnels. For instance, if prairie dogs follow certain soil strata when digging (King 1984), the chance of intersecting another tunnel might increase. Also, prairie dogs might detect existing tunnels via sound or odor. Indeed, such detections seem possible in prairie dog habitats, as exemplified in a study involving Siberian polecats (Mustela eversmanii) used as research surrogates for ferrets (Biggins et al. 2011); an American badger seemed to locate a prairie dog burrow with a polecat in it and began dig- ging directly toward a radio-tagged polecat that was below it rather than excavating at the opening of the burrow, which was several meters distant (DEB unpublished observation). Some burrowing mammals may be able to perceive seismic cues (Reichman and Smith 1990).

Burrow plugging and excavation in the prairie dog ecosystem is of theoretical interest, providing opportunities to investigate several modes of direct and indirect interactions among multiple mesopredators and their prey. Within the geographic area of this study, several findings seem noteworthy, collectively suggesting ferrets have impacts on the Badlands-Conata Basin complexes of prairie dog colonies that go far beyond the direct killing of prairie dogs as prey. Nevertheless, general conclusions in the context of burrow relationships among prairie dogs, ferrets, and other predators await replication of these kinds of studies and others at sites over the broad range of the black-tailed prairie dog and at sites with other prairie dog species.

\section{ACKNOWLEDGMENTS}

Support for this study was provided by the United States Geological Survey, the United States Fish and Wildlife Service, and the Denver Zoological Foundation. We thank the USDA Forest Service (FS) and the National Park Service (NPS) for allowing access to lands they administer. We especially appreciate the collaborative and operational assistance of Randy Griebel (FS), Brian Kenner (NPS), Greg Schroeder (NPS), Joshua Delger (NPS), Travis Livieri (Prairie Wildlife Research), and volunteer Darla Konkel. We are grateful for the reviews of E. Hellgren, B. Kenner, and P. Stevens. Any use of trade, product, or firm names is for descriptive purposes only and does not imply endorsement by the U.S. federal government.

\section{Literature Cited}

BALTAZARD, M. 1964. The conservation of plague in inveterate foci. Journal of Hygiene, Epidemiology, Microbiology, and Immunology 120:409-421.

Biggins, D.E. 2000. Predation on black-footed ferrets (Mustela nigripes) and Siberian polecats (M. eversmannii): conservation and evolutionary implications. Doctoral dissertation, Colorado State University, Fort Collins.

Biggins, D.E. 2012. Use of multi-opening burrow systems by black-footed ferrets. Western North American Naturalist 72:134-139. 
Biggins, D.E, L.R. Hanebury, and K.A. Fagerstone. 2012. Digging behaviors of radio-tagged blackfooted ferrets near Meeteetse, Wyoming, 19811984. Western North American Naturalist 72: 148-157.

Biggins, D.E., J.L. Godbey, K.L. Gage, L.G. Carter, AND J.A. Montenieri. 2010. Vector control improves survival of three species of prairie dogs (Cynomys) in areas considered enzootic for plague. Vector-Borne and Zoonotic Diseases 10:17-26.

Biggins, D.E., J.L. Godbey, M.R. Matchett, L.R. Hanebury, T.M. Livieri, AND P.E. Marinari. 2006a. Monitoring black-footed ferrets during reestablishment of free-ranging populations: discussion of alternative methods and recommended minimum standards. Pages 155-174 in J.E. Roelle, B.J. Miller J.L. Godbey, and D.E. Biggins, editors, Recovery of the black-footed ferret: progress and continuing challenges. U.S. Geological Survey Scientific Investigations Report 2005-5293, Fort Collins, CO.

Biggins, D.E., J.L. Godbey, B.J. Miller, and L.R. HANEBURY. 2006b. Radio-telemetry for black-footed ferret research and monitoring. Pages 175-189 in J.E. Roelle, B.J. Miller, J.L. Godbey, and D.E. Biggins, editors, Recovery of the black-footed ferretprogress and continuing challenges. U.S. Geological Survey Scientific Investigations Report 2005-5293.

Biggins, D.E., J.M. LOCKHART, AND J.L.Godbey. 2006c. Evaluating habitat for black-footed ferrets: revision of a former model. Pages 143-150 in J.E. Roelle, B.J Miller, J.L. Godbey, and D.E. Biggins, editors, Recovery of the black-footed ferret-progress and continuing challenges. U.S. Geological Survey Scientific Investigations Report 2005-5293, Fort Collins, CO

Biggins, D., B. Miller, L. Hanebury, R. Oakleaf, A. Farmer, R. Crete, AND A. Dood. 1993. A technique for evaluating black-footed ferret habitat. Pages 73-88 in J. Oldemeyer, D. Biggins, B. Miller, and R. Crete, editors, Management of prairie dog complexes for reintroduction of the black-footed ferret. U.S. Fish and Wildlife Service, Biological Report 93(13).

Biggins, D.E., B.J. Miller, L.R. Hanebury, and RA. PowELL. 2011. Mortality of Siberian polecats and black-footed ferrets released onto prairie dog colonies. Journal of Mammalogy 92:721-731.

Bozinovic, F., M.J. Carter, and L.A. Ebensperger. 2005. A test of the thermal-stress and cost-of-burrowing hypotheses among populations of the subterranean rodent Spalacopus cyanus. Comparative Biochemistry and Physiology, Part A 140:329-336.

Campbell, T.M., III, and T.W. Clark. 1981. Colony characteristics and vertebrate associates of white-tailed and black-tailed prairie dogs in Wyoming. American Midland Naturalist 105:269-276.

Campbell, T.M., III, T.W. Clark, L. Richardson, S.C. Forrest, and B.R. Houston. 1987. Food habits of Wyoming black-footed ferrets. American Midland Naturalist 117:208-210.

Clark, T.W. 1989. Conservation biology of the blackfooted ferret Mustela nigripes. Wildlife Preservation Trust Special Scientific Report Number 3, EcoHealth Alliance, New York. NY.

Creel, S., and D. Christianson. 2008. Relationships between direct predation and risk effects. Trends in Ecology and Evolution 23:194-201.
De Boer, S.F., and J.M. Koolhaas. 2003. Defensive burying in rodents: ethology, neurobiology and psychopharmacology. European Journal of Pharmacology 473:145-161.

EADS, D.A., AND D.E. BIGGINS. 2008. Aboveground predation by an American badger (Taxidea taxus) on black-tailed prairie dogs (Cynomys ludovicianus). Western North American Naturalist 68:396-401.

Eads, D.A., And D.E. BigGins. 2012. Patterns of surface burrow plugging in a colony of black-tailed prairie dogs occupied by black-footed ferrets. Western North American Naturalist 72:172-178.

Ebensperger, L.A., and D.T. Blumstein. 2007. Nonparental infanticide. Pages 267-279 in J.O. Wolf and P.W. Sherman, editors, Rodent societies: an ecological and evolutionary perspective. University of Chicago Press, Chicago, IL.

Fortenbery, D.K. 1972. Characteristics of black-footed ferrets. U.S. Fish Wildlife Service Resource Publication 109.

GaGe, K.L., AND M.Y. Kosoy. 2005. Natural history of plague: perspectives from more than a century of research. Annual Review of Entomology 50: 505-528.

HaLPIN, Z.T. 1983. Naturally occurring encounters between black-tailed prairie dogs (Cynomys ludovicianus) and snakes. American Midland Naturalist 109:50-54.

Hanksi, I., L. Hansson, and H. Henttonen. 1991. Specialist predators, generalist predators, and the microtine rodent cycle. Journal of Animal Ecology 60:353-367.

Hassell, M.P., and R.M. May. 1986. Generalist and specialist natural enemies in insect predator-prey interactions. Journal of Animal Ecology 55:923-940.

Henderson, F.R., P.F. Springer, And R. Adrian. 1969. The black-footed ferret in South Dakota. South Dakota Department of Game, Fish and Parks, Technical Bulletin 4:1-37.

Hillman, C.N. 1968. Life history and ecology of the black-footed ferret in the wild. Master's thesis, South Dakota State University, Brookings, SD.

Hillman, C.N., AND R.L. Linder. 1973. The black-footed ferret. Pages 10-20 in R.L. Linder and C.N. Hillman, editors, Proceedings of the black-footed ferret and prairie dog workshop. South Dakota State University, Brookings, SD.

Hoogland, J.L. 1995. The black-tailed prairie dog: social life of a burrowing mammal. University of Chicago Press, Chicago, IL.

Hoogland, J.L. 1996. Cynomys ludovicianus. Mammalian Species 535:1-10.

KING, J.A. 1955. Social behavior, social organization, and population dynamics in a black-tailed prairie dog town in the Black Hills of South Dakota. University of Michigan, Contributions of the Laboratory of Vertebrate Biology 67:1-123.

KING, J.A. 1984. Historical ventilations on a prairie dog town. Pages 447-456 in J.O. Murie and G.R. Michener, editors, The biology of ground-dwelling squirrels. University of Nebraska Press, Lincoln, NE.

King, W.J., M. Festa-Bianchet, and S.E. Hatfield. 1991. Determinants of reproductive success in female Columbian ground squirrels. Oecologia 86: $528-534$.

Koford, C.B. 1958. Prairie dogs, whitefaces, and blue grama. Wildlife Monographs 3:1-78. 
Krasnov, B.R. 2008. Functional and evolutionary ecology of fleas: a model for ecological parasitology. Cambridge University Press, Cambridge, United Kingdom.

Lehmer, E.M., L.T. Savage, M.F. Antolin, and D.E. BIGGINS. 2006. Extreme plasticity in thermoregulatory behaviors of free-ranging black-tailed prairie dogs. Physiological and Biochemical Zoology 79: 454-457.

LunA, F., AND C. Antinuchi. 2007. Effect of tunnel inclination on digging energetics in the tuco-tuco, Ctenomys talarum. Naturwissenschaften 94:100-106.

Matchett, M.R., D.E. Biggins, V. Carlson, B. Powell, AND T. RockIE. 2010. Enzootic plague reduces blackfooted ferret (Mustela nigripes) survival in Montana. Vector-Borne and Zoonotic Diseases 10:27-35.

Martin, S.J., M.H. Schroeder, and H. Tietjen. 1984. Burrow plugging by prairie dogs in response to Siberian polecats. Great Basin Naturalist 44:447-449.

MCLEAN, I.G. 1978. Plugging of nest burrows by female Spermophilus columbianus. Journal of Mammalogy 59:437-439.

Michener, G.R. 2004. Hunting techniques and tool use by North American badgers preying on Richardson's ground squirrels. Journal of Mammalogy 85: 1019-1027.

Reeve, A.F., And T.C. Vosburgh. 2006. Shooting prairie dogs. Pages 119-128 in J.E. Roelle, B.J. Miller, J.L. Godbey, and D.E. Biggins, editors, Recovery of the black-footed ferret: progress and continuing challenges. U.S. Geological Survey Scientific Investigations Report 2005-5293, Fort Collins, CO

Reichman, O.J., AND S.G. SMith. 1990. Burrows and burrowing behavior by mammals. Pages 197-244 in H.H. Genoways, editor, Current mammalogy. Plenum Press, New York, NY.

Reynolds, H.G. 1960. Life history notes on Merriam's kangaroo rat in southern Arizona. Journal of Mammalogy 41:48-58.

SheETs, R.G. 1970. Ecology of the black-footed ferret and the black-tailed prairie dog. Master's thesis, South Dakota State University, Brookings, SD.

Sheets, R.G., R.L. Linder, And R.B. DAhlgREn. 1971. Burrow systems of prairie dogs in South Dakota. Journal of Mammalogy 52:451-453.

1972. Food habits of two litters of black-footed ferrets in South Dakota. American Midland Naturalist 87:249-251.
Smith, R.E. 1958. Natural history of the prairie dog in Kansas. University of Kansas Museum of Natural History, Miscellaneous Publication.

StromberG, M.R. 1978. Subsurface burrow connections and entrance spatial pattern of prairie dogs. Southwestern Naturalist 23:173-180.

Thomas, K.R. 1974. Burrow systems of the eastern chipmunk (Tamias striatus pipilans Lowery) in Louisiana. Journal of Mammalogy 55:454-459.

Van Horne, B. 2007. Conservation of ground squirrels. Pages 463-471 in J.O. Wolf and P.W. Sherman, editors, Rodent societies: an ecological and evolutionary perspective. University of Chicago Press, Chicago, IL.

Verdolin, J.L., K. Lewis, and C.N. Slobodchikoff. 2008. Morphology of burrow systems: a comparison of Gunnison's (Cynomys gunnisoni), white-tailed (C. leucurus), black-tailed (C. ludovicianus), and Utah (C. parvidens) prairie dogs. Southwestern Naturalist 5:3:201-207.

VLECK, D. 1979. The energy cost of burrowing by the pocket gopher Thomomys bottae. Physiological Zoology 52:122-136.

VLECK, D. 1981. Burrow structure and foraging costs in the fossorial rodent, Thomomys bottae. Oecologia 49:391-396.

Vogel, S., C.P. Ellington, and D.L. Kilgore. 1973. Wind-induced ventilation of the burrow of the prairie-dog, Cynomys ludovicianus. Journal of Comparative Physiology 85:1-14.

Werner, S.J., D.L. Nolte, And F.D. Provenza. 2005. Proximal cues of pocket gopher burrow plugging behavior: influence of light, burrow openings, and temperature. Physiology and Behavior 85:340-345.

Wilcomb, M.J. 1954. A study of prairie dog burrow systems and the ecology of their arthropod inhabitants in central Oklahoma. Doctoral dissertation, University of Oklahoma, Lincoln, NE.

White, J.A. 2009. Summer burrows of Ord's kangaroo rats (Dipodomys ordii) in western Nebraska: food content and structure. Western North American Naturalist 69:469-474.

Received 18 April 2011

Accepted 30 January 2012 